\title{
Effect of Flag Leaf Clipping on Growth, Yield and Yield Attributes of Hybrid Rice in Boro Season
}

\author{
Sumya Fatima ${ }^{1}$, Md. Rasal-Monir ${ }^{2,}$, Meer Rifath Jahan Usha ${ }^{2}$, Md. Moinul Haque ${ }^{1}$ \\ ${ }^{1}$ Department of Agricultural Botany, Sher-e-Bangla Agricultural University, Dhaka, Bangladesh \\ ${ }^{2}$ Department of Horticulture, Sher-e-Bangla Agricultural University, Dhaka, Bangladesh
}

Email address:

monirr718@gmail.com (Md. Rasal-Monir)

${ }^{*}$ Corresponding author

\section{To cite this article:}

Sumya Fatima, Md. Rasal-Monir, Meer Rifath Jahan Usha, Md. Moinul Haque. Effect of Flag Leaf Clipping on Growth, Yield and Yield Attributes of Hybrid Rice in Boro Season. American Journal of Biological and Environmental Statistics. Vol. 5, No. 2, 2019 , pp. 21-30. doi: 10.11648/j.ajbes.20190502.12

Received: June 24, 2019; Accepted: July 17, 2019; Published: July 30, 2019

\begin{abstract}
The experiment was carried out at the Experimental Field of Agricultural Botany Department, Sher-e-Bangla Agricultural University, Dhaka-1207, Bangladesh, during October, 2017 to May, 2018 to study rice varieties (viz. BRRI Hybriddhan1, BRRI hybrid dhan2, Heera2, Heera4, Nobin and Moyna) were used for this study. The experiment was laid out in Split-plot Design with three replications. All the test varieties exhibited superiority in control condition. The tallest plant (115.2) was recorded from Moyna at harvest effect of flag leaf clipping on growth yield, and yield attributes of hybrid rice varieties in Boro season. Six hybrid stage and higher individual flag leaf area $\left(81.61 \mathrm{~cm}^{2}\right)$ was observed from Heera4. Penultimate leaf area and third leaf area $\left(78.98 \mathrm{~cm}^{2}\right.$ and $46.95 \mathrm{~cm}^{2}$, respectively) were obtained from BARIhybriddhan2. The highest number of leaves (67.33) and spikelet panicle ${ }^{-1}$ (219) were observed from Heera4. Among test rice varieties, higher grain yield $\left(6.01\right.$ tha $\left.^{-1}\right)$ and biological yield $\left(13.45 \mathrm{tha}^{-1}\right)$ were also achieved from Heera4. Days to maturity was significantly varied from 123 (Nobin) to 145 (BRRI Hybriddhan ${ }^{1}$ ) among the studied varieties. Chlorophyll content (SPAD value) in penultimate leaf after 15 days after heading, grain filling duration, yield contributing characters and yield were investigated after cutting of flag leaf. Regardless of variety, all the studied parameters were exhibited superiority in control treatment. Chlorophyll and nitrogen content (SPAD value) in penultimate $(1.35 \%$ to $17.27 \%)$ and grain filling duration were increased (4.5 to 6.25 days) by virtue of clipping of flag leaf. The highest number of effective tillers hill ${ }^{-1}$, filled grains panicle ${ }^{-1}$, weight of 1000 grains, grain yield, straw yield, biological yield were recorded from Heera4 under control condition. The clipping of the flag leaf reduced grain yield from $15.69 \%$ to $29.43 \%$ in the test Boro rice varieties.
\end{abstract}

Keywords: Flag Leaf, Growth, Yield, Hybrid Rice, Boro Season

\section{Introduction}

Rice (Oryza sativa L.) is the primary food of about $65 \%$ of the world's population [1]. Asia accounts for $90 \%$ of the world's production of rice.. In Bangladesh rice occupies its $77 \%$ of the total cropped area, contributes about $70-80 \%$ of total food grain production and continues to play a vital role in the national food and livelihood security system. Now the position of Bangladesh is $4^{\text {th }}$ in both area and production, and $6^{\text {th }}$ for the production of per hectare yield of rice [2, 3]. In the world rice are cultivated that covers total area of about 160 million hectares and also producing more than 700 million tons every year. It is also known as a main staple food for over half of the world's population, especially in South-east Asia along with rapidly growing populations [4]. It is reported that, more than $90 \%$ of all produced rice has been consumed in Asia [2]. It is rice that covers on an average of $20 \%$ apparent calorie intake in the world and also $30 \%$ for the Asian people [5]. Rice is the main staple food and also the source of major energy for Bangladeshi people that covers $80 \%$ of the total cropped area as about 12 million hectares [6]. It is strongly reported that about 10.4 million hectares of land in Bangladesh is used for the cultivation of rice which is about $85 \%$ of total cropped area and the annual production of Rice is 30.42 million tons [7]. 
The demand of rice is constantly increasing in Bangladesh with nearly three million people are being added each year to the total population of the country. To meet the food demand of the growing population and to achieve food security, the present production level needs to be increased. The recent yield level of modern rice varieties has reached to its plateau. Hybrid rice cultivation in Bangladesh has been gaining quick ground since then due to its higher yield over conventional inbred varieties. Hybrid rice has higher seedling dry matter content, thicker leaves, larger leaf area and long root system [6]. Hybrid rice can give yield advantage over modern inbred varieties through vigorous growth, extensive root system, efficient and greater sink size, greater carbohydrate translocation from vegetative parts to spikelets and larger leaf area index during the grain filling stage [8]. Dry matter production at different stages show different patterns for hybrid and inbred rice. Hybrid rice has more dry matter accumulation in the early and middle growth stages while inbred has more in the late growth stages. So, the growth patterns of hybrid rice have been found to be different from that of conventional inbred varieties in several ways.

Aus, Aman and Boro are three distinct growing seasons for Rice in our country. According to the report of FAO (2016), the average yield of rice in Bangladesh is about $2.92 \mathrm{t} \mathrm{ha}^{-1}$ that is very low than the other rice growing countries of the world, such as China $\left(6.30 \mathrm{t} \mathrm{ha}^{-1}\right)$, Japan $\left(6.60 \mathrm{t} \mathrm{ha}^{-1}\right)$ and Korea $\left(6.30 \mathrm{tha}^{-1}\right)$. In this condition, the crop production has to be increased at least $60 \%$ by 2020 so that we can meet up our food demand for the growing population [8]. Over population and their demand for the grain have been increasing day by day while crop cultivating area is showing negative trend. Now-a-days, soil fertility has decreased because of shorter fallow periods and the latter has not been compensated for by use of chemical fertilizer or organic manure. For these reasons yields have been fluctuating than before period of time with an overall negative trend. The result of food shortages have led to increase rice importation that leads to drain the country's foreign exchange.

Economic implications include high consumer prices, problems for the balance of payments, and the burden of external debt. One of the important aims for the cultivation of rice is yield. However, grain yield which is a complex trait and the genetic control of grain yield is a series of biochemical and physiological processes that is also very complex [9]. The flag leaf, penultimate leaves and the ear of the upper part of the plants that are responsible for photosynthesis of carbohydrate [10]. Plant leaves are the main organ of photosynthesis that is considered as the important determinant and they are also characterized for higher photosynthetic capacities [11].

Flag leafs that plays an important role in synthesis and also help for the translocation of photo-assimilates to the rice grains that affects grain yield. The uppermost leaf which is situated below the panicle is called flag leaf that provides the most important source of photosynthetic energy during reproduction. There are many evidence that Flag leaf is metabolically active than the other parts and has proved that the flag leaf, stem and head are the closest source of food to the grain $[11,12]$. Flag leaf is assigned as an important role for the supply of photosynthates to the grains [11]; for grain yield [13, 14] and for enhancing productivity [15]. The yield of grain and yield related traits hve positive relation to the area of flag leaf [16]. The top three leaves have most contribution for the yield of grain $[17,18]$. Intensive study was done on rice yield after clipping of flag leaf and nearby leaf [19]. By considering the importance of leaves for grain yield, it is necessary to analyze the morphological and the physiological characteristics of functional leaves to improve grain yield in rice [20]. Clipping of the flag leaf from rice at any stage after the emergence of panicle was the main cause of significant reduction in grain yield [21]. In another report it has shown that the contribution of flag leaf is as much as $45 \%$ on rice grain yield and, when it was removed, then it was the major component for the loss of rice yield [19]. 60$90 \%$ of total carbon in the panicles during harvest is derived from photosynthesis after heading, and $80 \%$ or more of nitrogen $(\mathrm{N})$ in the panicles during harvest is absorbed before heading which is remobilized from vegetative organs [22]. On the other hand, in case of wheat, above $34.5 \%$ grain yield reduction was reported after the clipping of flag leaf during the stage of heading [23]. while Birsin [24] showed that removal of flag leaf which resulted in approximately 13, 34, $24 \%$ reduction in grain per spike, grain weight per spike and 1000 -grain weight, respectively, and also increase $2.8 \%$ protein contents in grain. Similarly, it is believed that rice flag leaves are also a major source of remobilized minerals that is essential for the grains, and recent reports have tried to correlate the expression of gene levels on flag leaves with the concentration of mineral nutrients in rice grains $[25,26]$. However, research work on the role of flag and penultimate leaves (individually or combined) in yield formation of hybrid rice is limited in Bangladesh. But it is very essential to elucidate the contribution of different leaves in the formation of rice yield. Under these circumstances, the present research work was undertaken to investigate the growth behaviour of the hybrid rice varieties in Boro season and assess the effect of flag leaf clipping on the penultimate leaf chlorophyll content, duration of grain filling, yield and yield components of the hybrid rice varieties in Boro season.

\section{Methodology}

The experiment that was carried out at the experimental field of Sher-e-Bangla Agricultural University, Dhaka, Bangladesh during the period from November 2017 to May 2018 to the effect of flag leaf clipping on growth and yield of hybrid rice varieties. The soil belonged to "The Modhupur Tract", AEZ-28 (FAO, 1988). The texture of Top soilwas silty clay in texture, olive-gray with common fine to medium distinct dark yellowish brown mottles. Soil $\mathrm{pH}$ was 6.2 and it had $0.43 \%$ organic carbon.

\subsection{Climate}

The geographical location of the experimental site was 
under the subtropical climate which was characterized by three distinct seasons, winter season from November to February and hot season or the pre-monsoon period from March to April and monsoon period from May to October. Details of the meteorological data of rainfall, air temperature, relative humidity, and sunshine hour during the period of the experiment was collected from the Weather Station of Bangladesh, Sher-e Bangla Nagar, Dhaka.

\subsection{Treatments}

The experiment comprised of two factors. Factor A: Flag leaf clipping: 1. Clipping at heading 2. Control (without clipping). Factor B: Hybrid rice varieties (6) were used. $\mathrm{V}_{1}=$ BARI hybriddhan1, $\mathrm{V}_{2}=$ BARI hybriddhan2, $\mathrm{V}_{3}=$ Heera2, $\mathrm{V}_{4}=$ Heera $4, \mathrm{~V}_{5}=$ Nobin, $\mathrm{V}_{6}=$ Moyna.

\subsection{Experimental Design and Layout}

The experiment was laid out in a Randomized Complete Block Design (RCBD) with three replications. There were 36 plots for 12 treatment combinations each of 3 replications. A set of 12 treatment combinations were assigned at random in 12 pots of each replication.

\subsection{Seed Collection and Seed Sprouting}

The seeds of BRRI hybriddhan1, BRRI hybriddhan2, Heera-4, Heera-4, Nobin and Moyna were collected from Bangladesh Rice Research Institute (BRRI), Joydevpur, Gazipur and respective Seed Company, Dhaka. The seeds were collected just 20 days ahead of the sowing of seeds in seed bed.

Specific gravity method was used for selecting healthy seed and then immersed it was keep for 24 hours in water and then they were retain tightly in gunny bags. After 48 hours all seed began sprouting and were sown after 72 hours.

\subsection{Seed Bed Preparation and Seed Sowing}

As per BRRI recommendation seed bed was prepared with $1 \mathrm{~m}$ wide seed bed adding nutrients as per the requirements of soil. Seeds were sown in the seed bed on November 12 , 2018 in order to transplant the seedlings in the plot as per experimental design.

\subsection{Fertilizers and Manure Application}

Urea, TSP, MP, Gypsum, zinc sulphate and borax @ 80 kg, $60 \mathrm{~kg}, 90 \mathrm{~kg}, 12 \mathrm{~kg}, 2.0 \mathrm{~kg}$ and $10 \mathrm{~kg}$ were used respectively (BRRI, 2013). The entire amount of TSP, MP, gypsum, zinc sulphate and borax were applied during the final land preparation. Urea was applied in two equal portion as top dressing at tillering and panicle initiation stages.

\subsection{Uprooting of Seedlings and Transplanting of Seedlings in the Field}

The nursery bed was made wet by application of water one day before uprooting of the seedlings. The seedlings were uprooted on February 28, 2015 and March 31, 2016 for transplant on the date of $12^{\text {st }}$ March, 2016 and $12^{\text {st }}$ April, 2016 without causing much mechanical injury to the roots. On the scheduled dates as per experiment the rice seedlings were transplanted in lines each having a line to line distance of $30 \mathrm{~cm}$ and plant to plant distance $25 \mathrm{~cm}$ in the well prepared plots.

\subsection{Intercultural Operations and Plant Protection}

After establishment of seedlings, various intercultural operations were accomplished for better growth and development of the rice seedlings. First gap filling was done for all of the plots at 10 days after transplanting (DAT) by planting same aged seedlings. Flood irrigation was provided to maintain a constant level of standing water upto $6 \mathrm{~cm}$ in the early stages to enhance tillering and 10-12 cm in the later stage to discourage late tillering. The field was finally dried out at 15 days before harvesting. Gap filling was done for all of the plots at 10 days after transplanting (DAT) by planting same aged seedlings. Weeding was done to keep the plots free from weeds, which ultimately ensured better growth and development. The newly emerged weeds were uprooted carefully at tillering stage and at panicle initiation stage by mechanical means. After basal dose, the remaining doses of urea were top-dressed in 2 equal installments and were applied on both sides of seedlings rows in the soil.

Furadan 57 EC was applied at the time of final land preparation and later on other insecticides were applied as and when necessary.

\subsection{Harvesting, Threshing and Cleaning}

The rice was harvested depending upon the maturity of plant and harvesting was done manually from each plot. The harvested crop of each pot was bundled separately, properly tagged and brought to threshing floor. Enough care was taken during harvesting, threshing and also cleaning of rice seed. Fresh weight of grain and straw were recorded plot wise. The grains were cleaned and finally the weight was adjusted to a moisture content of $14 \%$. The straw was sun dried and the yields of grain and straw plot ${ }^{-1}$ were recorded and converted to $\mathrm{tha}^{-1}$.

\subsection{Data Collection and Statistical Analysis}

Three hills were selected randomly from the net plot area of each plot and tagged as sample plants. Two rows from all sides of the plot were left as border rows. The following observations were recorded from the sample plants and the mean values were worked out. Panicle Initiation (PI), Booting stage, Heading stage, Anthesis or Flowering stage, The Milk stage, The Dough Stage, The Maturity stage, Plant height, Leaf area, Tillers hill ${ }^{-1}$, Panicles hill ${ }^{-1}$, Spikelets panicle $^{-1}$, SPAD value, Duration of grain filling, Filled grain panicle $^{-1}$, Unfilled grains panicle ${ }^{-1}$, Weight of 1000 seeds, Yield, Grain yield, Straw yield, Biological yield.

The data obtained for different characters were statistically analyzed using MSTAT-C software to observe the significant 
difference among the different rice variety. The mean values of all the characters were calculated and factorial analysis of variance was performed. The significance of difference among the treatment means was estimated by the Least Significant Difference (LSD) at 5\% level of probability.

\section{Results and Discussion}

An experiment was carried out to assess the effect of flag leaf clipping on growth and yield of some rice varieties viz. BRRI hybriddhan1, BRRI hybriddhan2, Heera2, Heera4,
Nobin and Moyna.

\subsection{Plant Height}

Plant height at different days after transplanting showed statistically significant variation in studied hybrid rice varieties (Table 1). At harvest, the tallest plant $(115.2 \mathrm{~cm})$ was recorded from Moyna which was statistically different from all other treatments. The shortest plant $(99.43 \mathrm{~cm}$, respectively) at harvest was found from Nobin (Table 1).

Table 1. Effect of variety on plant height of the six rice hybrid varieties in Boro season.

\begin{tabular}{|c|c|c|c|c|c|c|c|c|c|}
\hline \multirow{3}{*}{$\begin{array}{l}\text { Treatment } \\
\text { BRRI hy. dhan1 }\end{array}$} & \multicolumn{9}{|c|}{ Plant height (cm) } \\
\hline & \multicolumn{2}{|c|}{40 DAT } & \multicolumn{2}{|c|}{55 DAT } & \multicolumn{2}{|c|}{70 DAT } & \multirow{2}{*}{$\begin{array}{l}\text { 85 DAT } \\
84.70\end{array}$} & \multicolumn{2}{|c|}{ At harvest } \\
\hline & 25.46 & $\mathrm{a}$ & 48.27 & $a b$ & 63.41 & $a b c$ & & 110.40 & $\mathrm{ab}$ \\
\hline BRRI hy. dhan2 & 20.88 & $\mathrm{bc}$ & 45.22 & $\mathrm{~b}$ & 55.19 & $\mathrm{c}$ & 83.10 & 103.80 & $\mathrm{~cd}$ \\
\hline Heera 2 & 19.03 & $\mathrm{c}$ & 44.00 & $\mathrm{~b}$ & 65.42 & $a b$ & 79.00 & 108.50 & bc \\
\hline Heera4 & 21.21 & $\mathrm{bc}$ & 44.71 & $a b$ & 58.83 & bc & 85.80 & 109.10 & bc \\
\hline Nobin & 20.43 & $\mathrm{bc}$ & 47.79 & $a b$ & 70.00 & $\mathrm{a}$ & 92.30 & 99.43 & $\mathrm{~d}$ \\
\hline Moyna & 22.50 & $a b$ & 49.64 & $\mathrm{a}$ & 64.93 & $a b c$ & 86.00 & 115.20 & $\mathrm{a}$ \\
\hline $\operatorname{LSD}(0.05)$ & 3.41 & & 4.19 & & 10.12 & & NS & 5.44 & \\
\hline $\mathrm{CV}(\%)$ & 10.75 & & 7.21 & & 6.65 & & 7.34 & 5.79 & \\
\hline
\end{tabular}

The values with same letter(s) in a column are not significantly different as per LSD test.

Different varieties produced different plant height on the basis of their varietal characters and improved varieties is the first and foremost requirement for initiation and accelerated production. Growth of rice is strongly influenced by genotype as well as environmental factors [27], Jisan et al. [28] reported that Hybrid Tia produced the tallest plant $(117.20 \mathrm{~cm})$.

\subsection{Leaf Number at Heading}

Leaf number at heading of different rice variety showed statistically significant variation under the present trial (Figure 1). The maximum number of leaf (67.33) was observed from Heera4 which were following (66.67 and 65.67) with BARI hybriddhan1 and BARI hybriddhan2, whereas the minimum number of leaf (57.67) from Moyna (Figure 1).

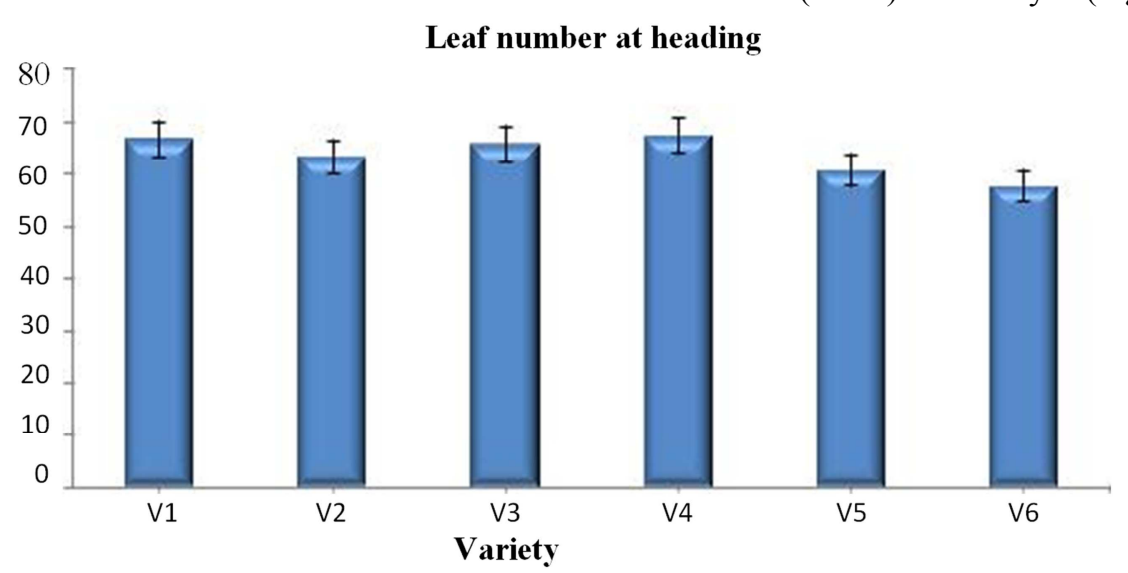

Figure 1. Effect of variety on leaf number of heading in the six rice hybrid varieties in Boro season [Vertical bar represents LSD values at 5\% level.] $V_{1}$ $=$ BRRI hybriddhan $1, V_{2}=$ BRRI hybriddhan $2, V_{3}=$ Heera $2, V_{4}=$ Heera $4, V_{5}=$ Nobin, $V_{6}=$ Moyna .

\subsection{Leaf Area}

Flag leaf, penultimate leaf and third leaf area of six hybrid rice varieties varied significantly in the Boro season (Figure 2). The highest flag leaf area index $\left(81.61 \mathrm{~cm}^{2}\right)$ was observed from Heera4, penultimate leaf and third leaf are index $(78.98$ $\mathrm{cm}^{2}$ and $46.95 \mathrm{~cm}^{2}$, respectively) was observed from BARI hybriddhan2, while the lowest leaf area $\left(48.37 \mathrm{~cm}^{2}, 52.42\right.$ $\mathrm{cm}^{2}$ and $20.55 \mathrm{~cm}^{2}$, respectively) was found from Moyna

\section{(Figure 2).}

Probably delayed planted crop prevailed lesser time in favor of growing environment which might have lowest leaf area of flag leaf. Jisan et al. [28] reported that BRRI dhan29 produced the leaf area, while the lowest values of these parameters were produced by BRRI dhan45. Similar results also reported by Amin et al. [29], Son et al. [30] and Shaloie et al. [31] from their earlier study. 


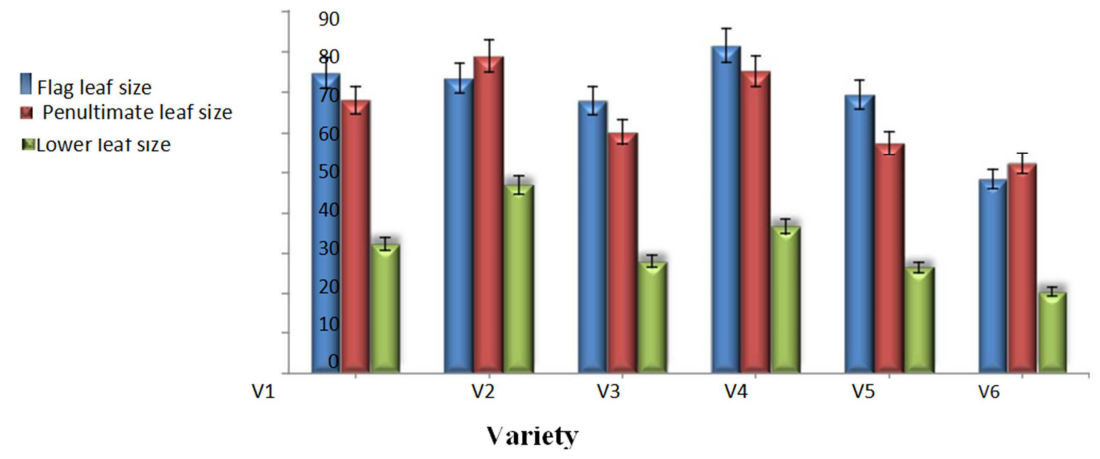

Figure 2. Effect of variety on leaf area of six rice hybrid varieties in Boro season [Vertical bars indicate LSD values at $5 \%$ level.] $V_{1}=$ BRRI hybriddhan1, $V_{2}=$ BRRI hybriddhan $2, V_{3}=$ Heera $2, V_{4}=$ Heera $4, V_{5}=$ Nobin, $V_{6}=$ Moyna .

\subsection{Days of Panicle Initiation, Booting Stage and Panicle Emergence}

Days of panicle initiation (PI) significantly affected due to variety to variety. Nobin takes the minimum days (75) for the panicle initiation while the maximum days (92) requires for panicle initiation in BRRI hybriddhan2 (Table 2).

The booting stage of rice significantly influenced due to varietal effect (Table 2). The highest days (104) require for the booting of rice plant in BRRI hybriddhan2 while the shortest days (85) was recorded in Nobin among all rice varieties.

The emergence of panicle in rice was progressively influenced by hybrid rice varieties (Table 2). BRRI dhan44 and Heera2 takes the minimum days (89) and maximum time days (111), respectively for the emergence of panicle among all genotypes.

\subsection{Days to 50\% Flowering}

Flowering in rice progressively varied due to varietal effect. The earliest 50\% flowering (98 days) was recorded in Heera4 while the maximum delaying flowering (116 days) was recorded by BRRI hybrid dhan2 among all of the hybrid rice varieties (Table 3 ).

Table 2. Different stages of the hybrid rice varieties in Boro season.

\begin{tabular}{llll}
\hline Variety & PI stage (days) & Booting stage (days) & PE stage (days) \\
\hline BRRI hybrid dhan1 & $88 \mathrm{ab}$ & $95 \mathrm{bc}$ & $102 \mathrm{c}$ \\
BRRI hybrid dhan2 & $92 \mathrm{a}$ & $104 \mathrm{a}$ & $107 \mathrm{~b}$ \\
Heera2 & $91 \mathrm{ab}$ & $103 \mathrm{a}$ & $111 \mathrm{a}$ \\
Heera & $85 \mathrm{bc}$ & $99 \mathrm{ab}$ & $103 \mathrm{c}$ \\
Nobin & $75 \mathrm{~d}$ & $85 \mathrm{~d}$ & $89 \mathrm{~d}$ \\
Moyna & $83 \mathrm{c}$ & $92 \mathrm{c}$ & $101 \mathrm{c}$ \\
LSD $(0.05)$ & 6.72 & 5.12 & 2.94 \\
CV $(\%)$ & 3.53 & 2.38 & 1.29 \\
\hline
\end{tabular}

The values with same letter(s) in a column are not significantly different as per LSD test.

\subsection{Milky Stage, Dough Stage and Maturity Stage}

Different hybrid rice varieties significantly varied in respect of the milky stage attended (Table 3). Heera4 took 103 days and BRRI hybriddhan2 maximum days (124) for milky stage among all the hybrid rice varieties.

In case of dough stage of rice progressively varied by varietal effect (Table 3). Among all genotypes, Heera4 produced earlier (112 days) and BRRI hybrid dhan2 and Heera2 achieved milky stage late (132 days).

Maturity stage was significantly varied among the studied varieties. BRRI hybrid dhan2 and Heera2 took the maximum days (145) to reach maturity. Nobin (123 days) reached the maturity earlier compared to the rest of the hybrid varieties (Table 3).

Table 3. Different stages of the hybrid rice varieties in Boro season.

\begin{tabular}{lllll}
\hline Variety & $\mathbf{5 0 \%}$ flowering (days) & Milky stage (days) & Dough stage (days) & Maturity stage (days) \\
\hline BRRI hybrid dhan1 & $105 \mathrm{~b}$ & $111 \mathrm{~b}$ & $122 \mathrm{~b}$ & $133 \mathrm{~b}$ \\
BRRI hybrid dhan2 & $116 \mathrm{a}$ & $124 \mathrm{a}$ & $132 \mathrm{a}$ & $145 \mathrm{a}$ \\
Heera2 & $115 \mathrm{a}$ & $123 \mathrm{a}$ & $132 \mathrm{a}$ & $145 \mathrm{a}$ \\
Heera4 & $105 \mathrm{~b}$ & $112 \mathrm{~b}$ & $123 \mathrm{~b}$ & $135 \mathrm{~b}$ \\
Nobin & $95 \mathrm{c}$ & $103 \mathrm{c}$ & $112 \mathrm{c}$ & $123 \mathrm{c}$ \\
Moyna & $104 \mathrm{~b}$ & $111 \mathrm{~b}$ & $122 \mathrm{~b}$ & $133 \mathrm{~b}$ \\
LSD & $4.29^{*}$ & $4.98^{* *}$ & $4.88^{* *}$ & $6.37^{* *}$ \\
CV $(\%)$ & 11.74 & 8.88 & 9.75 & 4.52 \\
\hline
\end{tabular}

The values with same letter(s) in a column are not significantly different as per LSD test. 


\subsection{SPAD Value of Penultimate Leaf and Grain Filling Duration}

Statistically significant variation was recorded for chlorophyll content (SPAD value) of at 15 days after heading. The highest chlorophyll content (SPAD value) in amount (46.5) was found from $\mathrm{T}_{1}$, whereas the lowest weight (43.38) was recorded from $\mathrm{T}_{2}$ (Table 3 ). Leaf cutting increases chlorophyll (SPAD value) in the penultimate leaf. These points indicated a compensatory increase in photosynthetic efficiency in the remaining leaves as shown by Robinson et al. (1992). Similarly, Myers and Ferree (1983) reported that defoliation of young apple trees caused an increased photosynthetic rate in the remaining leaves.

Chlorophyll content of penultimate leaf at 15 days and at maturity stage of varied significantly for different rice varieties (Table 4). The highest Chlorophyll content (46.52) was recorded from $\mathrm{V}_{2}$, which was statistically similar with $\mathrm{V}_{5}$ On the other hand, the lowest weight (43.29) was observed from $V_{6}$. Which were statistically similar with $V_{1}$ and $V_{3}$ (Table 1). Study showed that mean chlorophyll content among the cultivars varied significantly and suggested that the studied genotypes were genetically variable regarding chlorophyll content.

Combined effect of flag leaf cutting and rice varieties showed significant variation in chlorophyll content in penultimate leaves (Table 4). The highest SPAD value (48.31) was found from treatment combination of $\mathrm{T}_{1} \mathrm{~V}_{5}$ treatment combination and which was statistically similar with (47.7 and 47.22) was found $T_{1} V_{4}$ and $\mathrm{T}_{1} \mathrm{~V}_{2}$, the lowest (42.48) was recorded from treatment combination of $\mathrm{T}_{2} \mathrm{~V}_{6}$ treatment combination and which was statistically similar with (42.3) was recorded from $\mathrm{T}_{2} \mathrm{~V}_{4}$ (Table 4).

Table 4 showed that duration of grains filling was significantly different in both control and flag leaf removal treatment regardless of variety. Rice plant required 31.83 days for grain filling in flag leaf clipping treatment and around 28.40 days in control, respectively to fill the grains. It might be happened due to slow supply of assimilate to the grain.

Table 4. Effect of flag leaf clipping and variety on SPAD value in penultimate leaf and days to grain filling of the six rice hybrid varieties in Boro season.

\begin{tabular}{lllll}
\hline Treatment/variety & SPAD value & \multicolumn{3}{l}{ Days to grain filling } \\
\hline T1 & 46.62 & $\mathrm{a}$ & 31.83 & $\mathrm{~b}$ \\
$\mathrm{~T} 2$ & 43.41 & $\mathrm{~b}$ & 28.40 & $\mathrm{a}$ \\
$\mathrm{LSD}(0.05)$ & 2.17 & & 2.73 & \\
$\mathrm{~V} 1$ & 44.31 & $\mathrm{~b}$ & 28.53 & $\mathrm{c}$ \\
$\mathrm{V}_{2}$ & 46.52 & $\mathrm{a}$ & 31.34 & $\mathrm{a}$ \\
$\mathrm{V}_{3}$ & 43.73 & $\mathrm{~b}$ & 29.25 & $\mathrm{bc}$ \\
$\mathrm{V}_{4}$ & 45.01 & $\mathrm{a}$ & 31.12 & $\mathrm{a}$ \\
$\mathrm{V}_{5}$ & 46.31 & $\mathrm{a}$ & 27.57 & $\mathrm{c}$ \\
$\mathrm{V}_{6}$ & 43.29 & $\mathrm{~b}$ & 30.55 & $\mathrm{ab}$ \\
$\mathrm{LSD}(0.05)$ & 0.65 & & 1.63 & \\
CV \% & 5.73 & & 5.81 & \\
\hline
\end{tabular}

In a column, mean values having similar letter(s) are statistically identical and those having dissimilar letter(s) differ significantly at 0.05 level of significance. $\mathrm{T}_{1}=$ Flag leaf cutting, $\mathrm{T}_{2}=$ Control, $\mathrm{V}_{1}=\mathrm{BRRI}$ hybriddhan 1 , $\mathrm{V}_{2}=$ BARI hybriddhan $2, \mathrm{~V}_{3}=$ Heera $2, \mathrm{~V}_{4}=$ Heera $4, \mathrm{~V}_{5}=$ Nobin, $\mathrm{V}_{6}=$ Moyna
Among the varieties the maximum days required for grains filling (31.34 days) was recorded from BRRI hybriddhan2 whereas the minimum days required for Grains filling was attained from Heera2 which was 29.25 days (Table 4). The difference among the varieties might be related to the genetically characteristics of the varieties.

Wide range of variability was observed in respect of grains filling duration among six selected hybrid rice varieties (Table 4). Rice varieties viz. BRRI hybriddhan1, BRRI hybriddhan2, Heera2, Heera4, Nobin and Moyna plants took $26.37,28.23,28.83,28.67,28.30$ and 27.87 days, respectively for grain maturity under in control condition whereas it takes $31.28,34.41,29.63,33.34,32.34$ and 33.13 days under flag leaf clipping condition.

Table 5. Combined effect of flag leaf cutting and variety on SPAD value in penultimate leaf and days to grain filling of the six rice hybrid varieties in Boro season.

\begin{tabular}{lllll}
\hline Treatment combination & \multicolumn{2}{l}{ SPAD value } & \multicolumn{2}{l}{ Days to grain filling } \\
\hline $\mathrm{T}_{1} \mathrm{~V}_{1}$ & 44.42 & ef & 31.28 & $\mathrm{~d}$ \\
$\mathrm{~T}_{1} \mathrm{~V}_{2}$ & 47.20 & $\mathrm{~b}$ & 34.41 & $\mathrm{a}$ \\
$\mathrm{T}_{1} \mathrm{~V}_{3}$ & 46.31 & $\mathrm{c}$ & 29.63 & $\mathrm{e}$ \\
$\mathrm{T}_{1} \mathrm{~V}_{4}$ & 47.72 & $\mathrm{ab}$ & 33.34 & $\mathrm{~b}$ \\
$\mathrm{~T}_{1} \mathrm{~V}_{5}$ & 48.25 & $\mathrm{a}$ & 32.34 & $\mathrm{c}$ \\
$\mathrm{T}_{1} \mathrm{~V}_{6}$ & 45.18 & $\mathrm{de}$ & 33.13 & $\mathrm{~b}$ \\
$\mathrm{~T}_{2} \mathrm{~V}_{1}$ & 44.23 & $\mathrm{f}$ & 26.37 & $\mathrm{~h}$ \\
$\mathrm{~T}_{2} \mathrm{~V}_{2}$ & 45.82 & $\mathrm{~cd}$ & 28.25 & $\mathrm{f}$ \\
$\mathrm{T}_{2} \mathrm{~V}_{3}$ & 41.29 & $\mathrm{~h}$ & 28.83 & $\mathrm{ef}$ \\
$\mathrm{T}_{2} \mathrm{~V}_{4}$ & 42.35 & $\mathrm{~g}$ & 28.62 & $\mathrm{fg}$ \\
$\mathrm{T}_{2} \mathrm{~V}_{5}$ & 44.24 & ef & 26.33 & $\mathrm{~h}$ \\
$\mathrm{~T}_{2} \mathrm{~V}_{6}$ & 42.50 & $\mathrm{~g}$ & 27.81 & $\mathrm{~g}$ \\
$\mathrm{LSD}(0.05)$ & 0.89 & & 0.91 & \\
$\mathrm{CV} \%$ & 1.52 & & 4.86 & \\
\hline
\end{tabular}

In a column, mean values having similar letter(s) are statistically identical and those having dissimilar letter(s) differ significantly at 0.05 level of significance. $\mathrm{V}_{1}=\mathrm{BRRI}$ hybriddhan $1, \mathrm{~V}_{2}=\mathrm{BARI}$ hybriddhan $2, \mathrm{~V}_{3}=$ Heera2, $\mathrm{V}_{4}=$ Heera $4, \mathrm{~V}_{5}=$ Nobin, $\mathrm{V}_{6}=$ Moyna; $\mathrm{T}_{1}=$ Flag leaf cutting, $\mathrm{T}_{2}=$ Control.

\subsection{Filled Grain Panicle ${ }^{-1}$, Unfilled Grains Panicle ${ }^{-1}$ and Weight of 1000 Grains}

Statistically significant variation was recorded for filled grains panicle ${ }^{-1}$ due to flag leaf removal (Table 6). The highest filled grains panicle ${ }^{-1}(169.10)$ was recorded from $\mathrm{T}_{2}$, whereas the lowest (134.00) was obtained from $T_{1}$. Filled grains panicle ${ }^{-1}$ varied significantly for different rice varieties. The highest filled grains panicle ${ }^{-1}$ (179.70) was recorded from $\mathrm{V}_{4}$, which were statistically identical (169.70) to $V_{2}$, whereas the lowest (136.30) was found from $V_{6}$ (Table 5). Murthy et al. (2004) recorded different number of filled spikelets for different variety.

Interaction effect of flag leaf removal and rice varieties showed significant variation on filled grains panicle ${ }^{-1}$. The highest filled grains panicle ${ }^{-1}$ (227.30) was recorded from treatment combination of $\mathrm{T}_{2} \mathrm{~V}_{2}$, while the lowest (112.00) was found from treatment combination of $\mathrm{T}_{1} \mathrm{~V}_{2}$ (Table 6).

Statistically significant variation was recorded for unfilled grains penicle $\mathrm{e}^{-1}$ due to flag leaves removal (Table 6). The highest unfilled grains panicle ${ }^{-1}(52.00)$ was recorded from 
$T_{1}$, whereas the lowest (23.00) was recorded from $T_{2}$. Unfilled grains panicle $^{-1}$ varied significantly for different rice varieties (Table 5). The highest unfilled grains panicle ${ }^{-1}$ (60.33) was observed from $V_{3}$, while the lowest (27.50) was observed from $\mathrm{V}_{1}$ (Table 5. BINA [6] conducted an experiment with four varieties/advance lines and reported significant variation in unfilled spikelets panicle ${ }^{-1}$. Combined effect of flag leaf removal and rice varieties showed significant variation on unfilled grains panicle ${ }^{-1}$ (Table 6). The highest unfilled grainspanicle ${ }^{-1}(101.70)$ was observed from treatment combination of $\mathrm{T}_{1} \mathrm{~V}_{3}$ again the lowest (17.67) was recorded from treatment combination of $\mathrm{T}_{1} \mathrm{~V}_{5}$.

Statistically significant variation was recorded for weight of 1000 seeds due to flag leaf removal (Table 6). The highest weight of 1000 seeds $(27.40 \mathrm{~g})$ was found from $\mathrm{T}_{2}$, whereas the lowest weight (23.83 g) was recorded from $\mathrm{T}_{1}$ (Table 5). Alim et al., [32] reported that better results are obtained from early transplanting than late transplanting. Weight of 1000 seeds varied significantly for different rice varieties (Table $5)$. The highest weight of 1000 seeds $(28.55 \mathrm{~g})$ was recorded from $\mathrm{V}_{4}$, On the other hand, the lowest weight (21.56 g) was observed from $\mathrm{V}_{6}$ (Table 6). Bhowmick and Nayak [33] conducted an experiment with two hybrids (CNHR2 and CNHR3) and two high yielding varieties (IR36 and IR64) of rice and five levels of nitrogenous fertilizers and observed that IR36 gave the highest 1000-grain weight (21.07 g). Wang et al. [34] reported that compared with conventional cultivars, the hybrids had heavier seeds. Combined effect of flag leaf removal and rice varieties showed significant variation on weight of 1000 seeds (Table 6). The highest weight of 1000 seeds $(30.27 \mathrm{~g})$ was found from treatment combination of $\mathrm{T}_{2} \mathrm{~V}_{4}$ and the lowest $(22.62 \mathrm{~g})$ was recorded from treatment combination of $\mathrm{T}_{1} \mathrm{~V}_{6}$.

After harvesting 1000 grains weight from leaf cut plant was measured and significant reduction of weight was observed compare to 1000 grains weight of the control plant.

Table 6. Effect of flag leaf clipping and variety on yield components of the six rice hybrid varieties in Boro season.

\begin{tabular}{|c|c|c|c|c|c|c|c|c|}
\hline \multirow{3}{*}{$\begin{array}{l}\text { Treatment/variety } \\
\mathrm{T} 1\end{array}$} & \multirow{2}{*}{\multicolumn{2}{|c|}{$\begin{array}{l}\text { Effective } \\
\text { tillers hill }^{-1} \\
\end{array}$}} & \multirow{2}{*}{\multicolumn{2}{|c|}{$\begin{array}{l}\text { Filled grain } \\
\text { panicle }^{-1}\end{array}$}} & \multirow{2}{*}{\multicolumn{2}{|c|}{$\begin{array}{l}\text { Unfilled } \\
\text { grains panicle }^{-1}\end{array}$}} & \multirow{2}{*}{\multicolumn{2}{|c|}{$\begin{array}{l}\text { Weight of } \\
1000 \text { grains }\end{array}$}} \\
\hline & & & & & & & & \\
\hline & 11.56 & $\mathrm{~b}$ & 134.00 & $\mathrm{~b}$ & 52.00 & $\mathrm{a}$ & 23.83 & $\mathrm{~b}$ \\
\hline $\mathrm{T} 2$ & 12.50 & a & 169.10 & a & 23.00 & $\mathrm{~b}$ & 27.40 & a \\
\hline $\operatorname{LSD}(0.05)$ & 0.75 & & 12.23 & & 5.21 & & 0.33 & \\
\hline $\mathrm{V}_{1}$ & 12.83 & $\mathrm{~b}$ & 138.00 & $\mathrm{~cd}$ & 27.50 & d & 27.43 & $\mathrm{~b}$ \\
\hline $\mathrm{V}_{2}$ & 11.33 & $\mathrm{c}$ & 169.70 & $\mathrm{~b}$ & 41.00 & $\mathrm{~b}$ & 24.60 & d \\
\hline $\mathrm{V}_{3}$ & 11.00 & $\mathrm{c}$ & 139.70 & $\mathrm{~cd}$ & 60.33 & $\mathrm{a}$ & 24.82 & d \\
\hline V5 & 12.67 & $\mathrm{~b}$ & 146.00 & $\mathrm{c}$ & 19.50 & e & 26.74 & $\mathrm{c}$ \\
\hline V6 & 9.17 & d & 136.30 & d & 37.67 & $\mathrm{c}$ & 21.56 & e \\
\hline $\operatorname{LSD}(0.05)$ & 0.69 & & 9.32 & & 2.28 & & 0.40 & \\
\hline $\mathrm{CV} \%$ & 4.78 & & 4.29 & & 5.08 & & 2.01 & \\
\hline
\end{tabular}

In a column, mean values having similar letter(s) are statistically identical and those having dissimilar letter(s) differ significantly at 0.05 level of significance. $\mathrm{V}_{1}=\mathrm{BRRI}$ hybriddhan $1, \mathrm{~V}_{2}=\mathrm{BARI}$ hybriddhan $2, \mathrm{~V}_{3}=$ Heera2, $\mathrm{V}_{4}=$ Heera $4, \mathrm{~V}_{5}=$ Nobin, $\mathrm{V}_{6}=$ Moyna; $_{1}=$ Flag leaf cutting, $\mathrm{T}_{2}=$ Control.

Table 7. Interaction effect of flag leaf clipping and variety on yield components of the six rice hybrid varieties in Boro season.

\begin{tabular}{|c|c|c|c|c|c|c|c|c|}
\hline \multirow{2}{*}{$\begin{array}{l}\text { Treatment combination } \\
T_{1} V_{1}\end{array}$} & \multicolumn{2}{|c|}{ Effective tillers hill $^{-1}$} & \multicolumn{2}{|c|}{ Filled grain panicle $^{-1}$} & \multicolumn{2}{|c|}{ Unfilled grains panicle $^{-1}$} & \multicolumn{2}{|c|}{ Weight of 1000 grains } \\
\hline & 12.67 & $\mathrm{c}$ & 124.00 & gh & 37.00 & $\mathrm{e}$ & 25.73 & e \\
\hline $\mathrm{T} 1 \mathrm{~V} 2$ & 11.33 & d & 142.00 & $\mathrm{~h}$ & 52.67 & $\mathrm{c}$ & 22.73 & $\mathrm{~h}$ \\
\hline $\mathrm{T}_{1} \mathrm{~V}_{3}$ & 10.33 & $\mathrm{e}$ & 145.70 & de & 101.70 & a & 23.05 & $\mathrm{gh}$ \\
\hline T1V4 & 15.00 & $\mathrm{ab}$ & 158.30 & $\mathrm{~cd}$ & 47.00 & d & 26.83 & $\mathrm{~d}$ \\
\hline $\mathrm{T}_{1} \mathrm{~V}_{5}$ & 11.00 & de & 126.00 & $\mathrm{fg}$ & 17.67 & $\mathrm{~h}$ & 24.97 & $\mathrm{f}$ \\
\hline $\mathrm{T}_{1} \mathrm{~V}_{6}$ & 9.00 & f & 138.00 & ef & 56.00 & $\mathrm{~b}$ & 22.62 & $\mathrm{~h}$ \\
\hline $\mathrm{T}_{2} \mathrm{~V}_{1}$ & 13.00 & $\mathrm{c}$ & 152.00 & d & 18.00 & $\mathrm{~h}$ & 29.12 & $\mathrm{~b}$ \\
\hline $\mathrm{T}_{2} \mathrm{~V}_{3}$ & 11.67 & $d$ & 133.70 & efg & 19.00 & $\mathrm{gh}$ & 26.55 & d \\
\hline $\mathrm{T}_{2} \mathrm{~V}_{4}$ & 15.33 & $\mathrm{a}$ & 201.00 & $\mathrm{~b}$ & 31.00 & $\mathrm{f}$ & 30.27 & $\mathrm{a}$ \\
\hline T2V5 & 14.33 & b & 166.00 & $\mathrm{c}$ & 21.33 & $\mathrm{~g}$ & 28.48 & c \\
\hline T2V6 & 9.33 & $\mathrm{f}$ & 134.70 & efg & 19.33 & $\mathrm{gh}$ & 23.47 & g \\
\hline $\operatorname{LSD}(0.05)$ & 0.97 & & 13.19 & & 3.23 & & 0.56 & \\
\hline $\mathrm{CV} \%$ & 4.78 & & 4.29 & & 5.08 & & 2.01 & \\
\hline
\end{tabular}

In a column, mean values having similar letter(s) are statistically identical and those having dissimilar letter(s) differ significantly at 0.05 level of significance. $\mathrm{V}_{1}=\mathrm{BRRI}$ hybriddhan $1, \mathrm{~V}_{2}=$ BARI hybriddhan2, $\mathrm{V}_{3}=$ Heera2, $\mathrm{V}_{4}=$ Heera $4, \mathrm{~V}_{5}=$ Nobin, $\mathrm{V}_{6}=$ Moyna; $\mathrm{T}_{1}=$ Flag leaf cutting, $\mathrm{T}_{2}=$ Control.

\subsection{Weight of Rice}

Statistically significant variation was recorded for dry weight of rice due to removal. The highest dry weight of rice $\left(4.57 \mathrm{t} \mathrm{ha}^{-1}\right)$ was recorded from $\mathrm{T}_{2}$, whereas the lowest $(3.67 \mathrm{t}$ $\mathrm{ha}^{-1}$ ) was recorded from $\mathrm{T}_{1}$.

Dry weight of rice varied significantly for different rice varieties (Table 7). The highest dry weight of rice $(4.83 \mathrm{t} \mathrm{ha}$ ${ }^{1}$ ) was observed from $V_{4}$, On the other hand, the lowest (3.06 $\mathrm{t} \mathrm{ha}^{-1}$ ) was observed from $\mathrm{V}_{6}$.

Interaction effect of flag leaf cutting and rice varieties showed significant variation on dry weight of rice yield (Table 8). The highest dry weight of rice $\left(5.25 \mathrm{t} \mathrm{ha}^{-1}\right)$ was 
observed from treatment combination of $\mathrm{T}_{2} \mathrm{~V}_{4}$, while the lowest $\left(2.55 \mathrm{t} \mathrm{ha}^{-1}\right)$ was recorded from treatment combination of $\mathrm{T}_{1} \mathrm{~V}_{6}$.

\subsection{Grain Yield, Straw Yield and Biological Yield}

Statistically significant variation was recorded for grain yield due to removal (Table 8$)$. The highest grain yield $(4.70 \mathrm{t}$ $\mathrm{ha}^{-1}$ ) was observed from $\mathrm{T}_{2}$, whereas the lowest $\left(3.73 \mathrm{t} \mathrm{ha}^{-1}\right)$ was recorded from $\mathrm{T}_{1}$ (Table 8 ). In that an optimum planting date exists and the planting before or after that optimum results in yield reduction of crops. Singh et al., [21]. reported that grain yield of rice markedly declined with delayed planting. These results are in agreement with earlier reports on the contribution of flag leaf and top three leaves to grain yield $[17,35,36]$.

Grain yield varied significantly for different rice varieties (Table 7). The highest grain yield (5.01 t ha was observed from $\mathrm{V}_{4}$, which were statistically followed (4.00 and $3.94 \mathrm{t}$ ha $^{-1}$ ) by $V_{3}$ and $V_{4}$, whereas the lowest $\left(3.12 \mathrm{t} \mathrm{ha}^{-1}\right)$ was observed from $\mathrm{V}_{6}$ (Table 5). Swain et al. [37] reported that the control cultivar IR64, with high translocation efficiency and 1000-grain weight and lowest spikelet sterility recorded a grain yield of $5.6 \mathrm{t} \mathrm{ha}^{-1}$ that was statistically similar to the hybrid line PA6201. Xie et al. [38] reported different yield for different variety.

Interaction effect of removal and rice varieties showed significant variation on grain yield (Table 8). The highest grain yield $\left(5.47 \mathrm{t} \mathrm{ha}{ }^{-1}\right)$ was found from treatment combination of $\mathrm{T}_{2} \mathrm{~V}_{4}$ and the lowest $\left(2.61 \mathrm{t} \mathrm{ha}^{-1}\right)$ was recorded from treatment combination of $\mathrm{T}_{1} \mathrm{~V}_{6}$.

Statistically significant variation was recorded for dry straw yield due to removal (Table 8). The highest dry straw yield $\left(7.29 \mathrm{t} \mathrm{ha}^{-1}\right)$ was recorded from $\mathrm{T}_{2}$, whereas the lowest $\left(5.84 \mathrm{t} \mathrm{ha}^{-1}\right)$ was recorded from $\mathrm{T}_{1}$.

Straw yield varied significantly for different rice varieties (Table 8). The highest straw yield $\left(7.44 \mathrm{t} \mathrm{ha}^{-1}\right)$ was observed from $\mathrm{V}_{4}$, which were statistically identical (6.50 and $\left.6.48 \mathrm{t} \mathrm{ha}^{-1}\right)$ to $V_{2}$ and $V_{3}$, which were statistically followed (6.41 and 6.44 $\mathrm{t} \mathrm{ha}^{-1}$ ) by $\mathrm{V}_{1}$ and $\mathrm{V}_{5}$. On the other hand, the lowest $\left(6.11 \mathrm{t} \mathrm{ha}^{-1}\right)$ was observed from $\mathrm{V}_{6}$. Interaction effect of flag leaf cutting and rice varieties showed significant variation on straw yield (Table 8$)$. The highest straw yield $\left(8.01 \mathrm{t} \mathrm{ha}^{-1}\right)$ was observed from treatment combination of $\mathrm{T}_{2} \mathrm{~V}_{4}$, while the lowest $(5.28 \mathrm{t}$ $\mathrm{ha}^{-1}$ ) was recorded from treatment combination of $\mathrm{T}_{1} \mathrm{~V}_{6}$.

Statistically significant variation was recorded for biological yield due to flag leaf cutting (Table 8). The highest biological yield (11.98 $\mathrm{t} \mathrm{ha}^{-1}$ ) was observed from $\mathrm{T}_{2}$, while the lowest $\left(9.57 \mathrm{t} \mathrm{ha}^{-1}\right)$ was found from $\mathrm{T}_{1}$. Kainth and Mehra, [39] reported that when transplanting is delayed beyond normal period, the grain development is very poor which results in more quantity of under developed grains and ultimately severe reduction in yield. Biological yield varied significantly for different rice varieties. The highest biological yield (12.45 $\mathrm{t} \mathrm{ha}^{-1}$ ) was recorded from $\mathrm{V}_{4}$, which were statistically identical $\left(11.11 \mathrm{t} \mathrm{ha}^{-1}\right)$ to $\mathrm{V}_{1}$ and followed $\left(10.95 \mathrm{t} \mathrm{ha}^{-1}\right)$ by $\mathrm{V}_{5}$, whereas the lowest $\left(9.23 \mathrm{t} \mathrm{ha}^{-1}\right)$ was found from $\mathrm{V}_{6}$.

Combined effect of flag leaf clipping and rice varieties showed significant variation on biological yield (Table 8). The highest biological yield $\left(13.48 \mathrm{t} \mathrm{ha}^{-1}\right)$ was attained from treatment combination of $\mathrm{T}_{2} \mathrm{~V}_{4}$ again the lowest $\left(7.87 \mathrm{t} \mathrm{ha}^{-1}\right)$ was found from treatment combination of $\mathrm{T}_{1} \mathrm{~V}_{6}$.

Table 8. Effect of flag leaf clipping and variety on yield of the six rice hybrid varieties in Boro season.

\begin{tabular}{|c|c|c|c|c|c|c|}
\hline \multirow{2}{*}{$\begin{array}{l}\text { Treatment/variety } \\
\mathrm{T} 1\end{array}$} & \multicolumn{2}{|c|}{ Grain yield $\left(\mathrm{t} \mathrm{ha}^{-1}\right)$} & \multicolumn{2}{|c|}{ Straw yield $\left(\mathrm{t} \mathrm{ha}^{-1}\right)$} & \multicolumn{2}{|c|}{ Biological yield $\left(\mathrm{t} \mathrm{ha}^{-1)}\right.$} \\
\hline & 4.73 & $\mathrm{~b}$ & 5.84 & $b$ & 10.57 & $\mathrm{~b}$ \\
\hline $\mathrm{T} 2$ & 5.70 & $\mathrm{a}$ & 7.29 & a & 12.98 & a \\
\hline $\operatorname{LSD}(0.05)$ & 0.18 & & 0.24 & & 0.26 & \\
\hline $\mathrm{V} 1$ & 5.71 & $\mathrm{~b}$ & 6.41 & $\mathrm{bc}$ & 12.11 & $\mathrm{~b}$ \\
\hline $\mathrm{V} 2$ & 4.94 & $\mathrm{~d}$ & 6.50 & $\mathrm{~b}$ & 11.44 & $\mathrm{c}$ \\
\hline $\mathrm{V}_{3}$ & 5.00 & $d$ & 6.48 & $\mathrm{~b}$ & 11.48 & $\mathrm{c}$ \\
\hline V4 & 6.01 & $\mathrm{a}$ & 7.44 & $\mathrm{a}$ & 13.45 & a \\
\hline $\mathrm{V}_{5}$ & 5.52 & $\mathrm{c}$ & 6.44 & $\mathrm{bc}$ & 11.95 & $\mathrm{~b}$ \\
\hline $\mathrm{V}_{6}$ & 4.12 & $\mathrm{e}$ & 6.11 & $\mathrm{c}$ & 10.23 & $\mathrm{~d}$ \\
\hline $\operatorname{LSD}(0.05)$ & 0.11 & & 0.34 & & 0.37 & \\
\hline $\mathrm{CV} \%$ & 2.34 & & 4.36 & & 2.83 & \\
\hline
\end{tabular}

In a column, mean values having similar letter(s) are statistically identical and those having dissimilar letter(s) differ significantly at 0.05 level of significance. $\mathrm{V}_{1}=$ BRRI hybriddhan $1, \mathrm{~V}_{2}=$ BARI hybriddhan $2, \mathrm{~V}_{3}=$ Heera2, $\mathrm{V}_{4}=$ Heera4, $\mathrm{V}_{5}=$ Nobin, $\mathrm{V}_{6}=$ Moyna; $\mathrm{T}_{1}=$ Flag leaf cutting, $\mathrm{T}_{2}=$ Control.

Table 9. Interaction effect of flag leaf removal and variety on on yield of the six rice hybrid varieties in Boro season.

\begin{tabular}{|c|c|c|c|c|c|c|}
\hline \multirow{2}{*}{$\begin{array}{l}\text { Treatment combination } \\
T_{1} V_{1}\end{array}$} & \multicolumn{2}{|c|}{ Grain yield $\left(\mathrm{t} \mathrm{ha}^{-1}\right)$} & \multicolumn{2}{|c|}{ Straw yield $\left(\mathrm{t} \mathrm{ha}^{-1}\right)$} & \multicolumn{2}{|c|}{ Biological yield $\left(\mathrm{t} \mathrm{ha}^{-1}\right)$} \\
\hline & 5.25 & $\mathrm{e}$ & 6.06 & $\mathrm{c}$ & 11.31 & de \\
\hline $\mathrm{T}_{1} \mathrm{~V}_{2}$ & 4.43 & $\mathrm{~h}$ & 5.19 & e & 9.63 & $\mathrm{~g}$ \\
\hline $\mathrm{T}_{1} \mathrm{~V}_{3}$ & 4.52 & gh & 5.79 & $\mathrm{~cd}$ & 10.31 & $\mathrm{f}$ \\
\hline $\mathrm{T}_{1} \mathrm{~V}_{4}$ & 5.54 & $\mathrm{~d}$ & 6.87 & $\mathrm{~b}$ & 12.41 & $\mathrm{c}$ \\
\hline $\mathrm{T}_{1} \mathrm{~V}_{5}$ & 5.05 & $\mathrm{f}$ & 5.82 & $\mathrm{~cd}$ & 10.87 & ef \\
\hline $\mathrm{T}_{1} \mathrm{~V}_{6}$ & 3.61 & $\mathrm{i}$ & 5.28 & de & 8.89 & $\mathrm{~h}$ \\
\hline $\mathrm{T}_{2} \mathrm{~V}_{1}$ & 6.16 & $\mathrm{~b}$ & 6.75 & $\mathrm{~b}$ & 12.91 & $\mathrm{bc}$ \\
\hline
\end{tabular}




\begin{tabular}{|c|c|c|c|c|c|c|}
\hline \multirow{2}{*}{$\begin{array}{l}\text { Treatment combination } \\
T_{2} V_{2}\end{array}$} & \multicolumn{2}{|c|}{ Grain yield $\left(\mathrm{t} \mathrm{ha}{ }^{-1}\right)$} & \multicolumn{2}{|c|}{ Straw yield $\left(\mathrm{t} \mathrm{ha}^{-1}\right)$} & \multicolumn{2}{|c|}{ Biological yield $\left(\mathrm{t} \mathrm{ha}^{-1}\right)$} \\
\hline & 5.45 & $\mathrm{~d}$ & 7.80 & $\mathrm{a}$ & 13.25 & $\mathrm{~b}$ \\
\hline $\mathrm{T}_{2} \mathrm{~V}_{3}$ & 5.48 & $\mathrm{~d}$ & 7.17 & $\mathrm{~b}$ & 12.65 & $\mathrm{bc}$ \\
\hline $\mathrm{T} 2 \mathrm{~V} 4$ & 6.47 & a & 8.01 & a & 14.48 & $\mathrm{a}$ \\
\hline $\mathrm{T}_{2} \mathrm{~V}_{5}$ & 5.99 & $\mathrm{c}$ & 7.05 & $\mathrm{~b}$ & 13.04 & $\mathrm{bc}$ \\
\hline $\mathrm{T}_{2} \mathrm{~V}_{6}$ & 4.61 & g & 6.93 & $\mathrm{~b}$ & 11.57 & d \\
\hline $\operatorname{LSD}_{(0.05)}$ & 0.15 & & 0.59 & & 0.63 & \\
\hline $\mathrm{CV} \%$ & 2.34 & & 4.63 & & 2.83 & \\
\hline
\end{tabular}

In a column, mean values having similar letter(s) are statistically identical and those having dissimilar letter(s) differ significantly at 0.05 level of significance. $\mathrm{V}_{1}=$ BRRI hybriddhan $1, \mathrm{~V}_{2}=$ BARI hybriddhan2, $\mathrm{V}_{3}=$ Heera2, $\mathrm{V}_{4}=$ Heera4, $\mathrm{V}_{5}=$ Nobin, $\mathrm{V}_{6}=$ Moyna; $\mathrm{T}_{1}=$ Flag leaf cutting, $\mathrm{T}_{2}=$ Control.

\section{Conclusion}

Heera4 provided the highest yield at leaf cutting and control condition among the studied hybrid varieties. On an average, grain yield reduced average $22.5 \%$ due to cutting of flag leaf. SPAD value (chlorophyll and nitrogen content) in penultimate leaves were increased from $1.35 \%$ to $17.27 \%$ and grain filling duration increased 4.5 day to 6.25 days due to removal of flag leaf in the studied varieties.

\section{Recommendation}

Heera4 should be cultivated to get higher yield in Boro season. For wider acceptability, the same experiment should be repeated at different agro-ecological zones of the country.

\section{References}

[1] Akter, S., Hossain M., Huda A., Islam M. R. and Jahiruddin M. (2014). Evaluation of growth, yield and nutrient content of some Boro rice cultivars. Res. Agric., Livest. Fish., 1 (1): 1925 .

[2] FAO, (Food and Agriculture Organization), (2006). Retrieved from: http//www.fao.org

[3] Sarkar, R.. K. and Reddy, J. N. (2006). Response of lowland rice (Oryza sativa) cultivars to different sowing dates during rainy season. Indian Council of Agricultural Research. New Delhi. India.

[4] Grist, H. D., (1988), Rice, Colonial agricultural service, Malaysia, Longman, London and New York.

[5] Hien, N. L., Yoshihashi, T. and Sarhadi, W. A. (2006). Evaluation of aroma in rice using $\mathrm{KOH}$ method, molecular markers and measurement of 2-acetyl-1-pyrroline concentration. Japanese J. Trop. Agric., 50: 190-198.

[6] BRRI, (1999). Bangladesh Rice Research Institute, Modern Rice Cultivar, 5: 11-18.

[7] BBS, (2014). Statistical Yearbook of Bangladesh. Bangladesh Bureau of Statistics. Statistics Division, Ministry of Planning, Govt. of Peoples Republic of Bangladesh. Dhaka. Bangladesh. p. 64.

[8] Langfield, E. C. B. and Basinski, J. J. (1960). The effect of time of planting on the behavior of rice varieties in northern Australia. Tropical Agric. Thrim., 37: 383-392.

[9] Ashraf, M., Akbar M. and Salim M.(1994). Genetic improvement in physiological traits of rice yield. In: Slafer G A, eds. Genetic Improvement of Field Crops. Marcel Dekker Incorporate, New York, P 413-455.

[10] Tambussi E. A., Bort. J., Guiamet J. J., Nogués S. and Araus J. L. (2007). The photosynthetic role of ears in C3 cereals: metabolism, water use efficiency and contribution to grain yield. Crit. Rev. Plant Sci., 26: 1-16.

[11] Asana, R. D. (1968). In quest of yield. Indian J. Plant Physiol., 11: 1-10.

[12] Ramadas V. S. and Rajendrudu G. (1977). The photosynthetic efficiency of flag leaf in relation to structural features in some crop plants. Indian J. Plant Physiol., 22: 123-128.

[13] Raj A. and Tripathi M. P. (2000). Varietal variations in flag leaf area and yield in deep water rice. Indian J. Plant Physiol. 5: 293-295.

[14] Sheela G., Shai V. N. and Saran. (1990). Role of flag leaf on grain yield and spikelet sterility in rice cultivars. Oryza, 27: 87-88.

[15] Padmaja R. S. (1991). Influence of source and sink on the production of high density grain and yield in rice. Indian $J$. Plant Physiol., 34: 329-348.

[16] Ashrafuzzaman, M. M., Islam R., Ismail M. R., Shahidullah S. M. and Hanafi M. M. (2009). Evaluation of six aromatic rice varieties for yield and yield contributing characters. Int. J. Agric. Biol., 11: 616-620.

[17] Yoshida S. (1981). Fundamentals of Rice Crop Science. International Rice Research Institute, Manila, Philippines. Los Baños, Laguna. 269 p.

[18] Misra A. N. (1987). Physiological aspects of grain formation in sorghum and pearl millet. In: Production technology for sorghum and pearl millet. ICAR/Sukhadia University, Jaipur, India, pp. 1-6.

[19] Abou-khalifa, A., Misra A. N. and Salem K. M. A. (2008). Effect of leaf cutting on physiological traits and yield of two rice cultivars. African J Plant Sci., 2: 147-150.

[20] Yue B., Xue W. Y., Luo L. J. and Xing Y. Z. (2006). QTL analysis for flag leaf characteristics and their relationships with yield and yield traits in rice. Acta Genetica Scinica, 2: 824-832.

[21] Singh T., Ghosh A. K. (1981): Effect of flag leaf on grain yield of transplanted rice. International Rice Research Institute, 6: 5 .

[22] Mae T. (1997). Physiological nitrogen efficiency in rice: Nitrogen utilization, photosynthesis, and yield potential. Plant and Soil, 196: 201-210. 
[23] Mahmood N. and Chowdhury M. A. (1997). Removal of green photosynthetic structures and their effect on some yield parameters in bread wheat. Wheat Information Service, 85: 14-20.

[24] Birsin, M. A. (2005): Effects of removal of some photosynthetic structures on some yield components in wheat. Tarim Bilimleri Dergisi J. Agricultural Sci., 11: 364-367.

[25] Narayanan N. N., Vasconcelos M. W., Grusak M. A. (2007), Expression profiling of Oryza sativa metal homeostasis genes in different rice cultivars using a cDNAmacroarray. Plant Physiology and Biochemistry, 45: 277-286.

[26] Sperotto R. A., Ricachenevsky F. K., Duarte G. L., Boff T., Lopes K. L., Sperb E. R., Grusak M. A., Fett J. P. (2009), Identification of up-regulated genes in flag leaves during rice grain filling andcharacterization of OsNAC5, a new ABAdependent transcription factor. Planta, 230: 985-1002.

[27] BRRI, (2003). Annual Internal Review, held on 19-23 October, 2003. Grain Quality and Nutrition Division. Bangladesh Rice Research Institute. pp. 1-20.

[28] Jisan M. T., Paul S. K., Salim M. (2014). Yield performance of some transplant Boro rice varieties as influenced by different levels of nitrogen. J. Bangladesh Agril. Univ., 12 (2): 311-324.

[29] Amin, M. R., Hamid, A., Choudhury, R. U., Raquibullah, S. M. and Asaduzzaman M. (2006). Nitrogen Fertilizer Effect on Tillering, Dry Matter Production and Yield of Traditional Varieties of Rice. Intl. J. Suatain. Crop Prod., 1 (1): 17-20.

[30] Son, Y., Park, S. T., Kim, S. Y., Lee, H. W. and Kim, S. C. (1998). Effects of plant density on the yield and yield components of low-tillering large panicle type rice. J. Crop Sci., 40: 2-10.

[31] Shaloie, M., Gilani, A. and Siadat, S. A. (2014). Evaluation of sowing date effect on hybrid rice lines production in dry-bed of Khuzestan. Intl. Res. J. Appl. Basic Sci., 8 (7): 775-779.

[32] Alim, M. G., Mannan, M. A., Halder, K. P. and Siddique, S. B. (1993). Effect of planting dates on the growth and yield of modern transplanted Boro rice. Ann. Bangladesh Agric., 32: 103-108.

[33] Bhowmick, N. and Nayak, R. L. (2000). Response of hybrid rice (Oryza sativa L.) varieties to nitrogen, phosphorus and potassium fertilizers during dry (Boro) season in West Bengal. Indian J. Agron., 45 (2): hybriddhan 13-326.

[34] Wang, J. L., Xu, Z. J. and Yi, X. Z. (2006). Effects of seedling quantity and row spacing on the yields and yield components of hybrid and conventional rice in northern China. Chinese $J$. Rice Sci., 20 (6): 631-637.

[35] Ray S., Mondal W. A., Choudhury M. A. (1983). Regulation of leaf senescence, grain-filling and yield of rice by kinetin and abscisic acid. Physiol. Plant, 59: 343-346.

[36] Misra A. N. and Misra M. (1986). Effect of temperature on senescing rice leaves. I. Photoelectron transport activity of chloroplasts. Plant Sci., 46: 1-4.

[37] Swain, P., Annie, P. and Rao, K. S. (2006). Evaluation of rice (Oryza sativa L.) hybrids in terms of growth and physiological parameters and their relationship with yield under transplanted condition. Indian J. Agric. Sci., 76 (8): 496-499.

[38] Xie, W., Wang, G. and Zhang, Q. (2007). Potential production simulation and optimal nutrient management of two hybrid rice varieties in Jinhua, Zhejiang Province. J. Zhejiang Univ. Sci., 8 (7): 486-492.

[39] Kainth, G. S. and Mehra, P. L. (1985). Rice Production: Potentials and Constraints. Inter India Publication. New Delhi 110015 . 